\title{
CELL CYCLE KINETICS AND DEVELOPMENT OF HYDRA ATTENUATA
}

\section{INTERSTITIAL CELLS}

\author{
R. D. CAMPBELL * AND C. N. DAVID $\dagger$
}

Max-Planck-Institut fïr Virusforschung, Molekularbiologische Abteilung, Tilbingen, Germany, and Department of Developmental and Cell Biology, University of California, Irvine, California 92664, U.S.A.

\begin{abstract}
SUMMARY
The cell cycle parameters of interstitial cells in Hydra attenuata have been determined. Interstitial cells were classified according to cluster size in which they occur $(1,2,4,8$ or 16 cells) and morphology using maceration preparations and histological sections. The lengths of $G_{1}, S, G_{2}$ and $M$ were determined by standard methods of cell cycle analysis using pulsechase and continuous labelling with $\left[{ }^{3} \mathrm{H}\right]$ - and $\left[{ }^{14} \mathrm{C}\right]$ thymidine. Nuclear DNA contents were measured microfluorimetrically. All classes of interstitial cells proliferate but the cell cycle of large interstitial cells occurring singly or in pairs is longer than that of interstitial cells occurring in clusters of 4,8 and $\mathrm{I} 6$ cells. The $S$-phase is $\mathrm{I} \mathrm{I}-\mathrm{I} 2 \mathrm{~h}$ long and $G_{1}$ is less than $\mathrm{I}$ h for all classes of interstitial cells. $G_{2}$ is $3-4 \mathrm{~h}$ long for interstitial cells in clusters of 4,8 and $\mathrm{i} 6$ cells giving these cells a total cell cycle duration of $16-17 \mathrm{~h}$. In contrast, large interstitial cells occurring as singles and in clusters of 2 have $G_{2}$ durations ranging from 4 to $22 \mathrm{~h}$. Two subpopulations can be discerned among these cells, one having a $G_{1}$ of about $6 \mathrm{~h}$ and a total cell cycle of about I $9 \mathrm{~h}$, the other having an average $G_{8}$ of $\mathrm{I}_{4} \mathrm{~h}$ and a total cell cycle of about $27 \mathrm{~h}$. The differences in cell cycle duration appear to be associated with interstitial cell function. Cells having a short cell cycle are probably committed to nematocyte differentiation, while large interstitial cells having long and variable cell cycles appear to be undetermined stem cells responsible for proliferating further interstitial cells. The variable length of $G_{2}$ in these cells suggest it as a possible control point.
\end{abstract}

\section{INTRODUCTION}

Interstitial cells of $H y d r a$ are one of the best known examples of a multipotent stem cell population. They are actively proliferating, morphologically undifferentiated precursors to all 4 types of hydra nematocytes (stinging cells) and several types of nerve cells as well as eggs and sperm in sexual animals (Lentz, I966; Burnett, 1968). The continuous proliferation and differentiation of interstitial cells in hydra results in a wide variety of undifferentiated and differentiated cells occurring in the interstitial cell positions of the ectoderm. However, because these cells are so numerous and densely packed, only slow progress has been made, using classical histological techniques, in interpreting this complex cell population.

- Present address: Department of Developmental and Cell Biology, University of California, Irvine, California 92664, U.S.A.

$\dagger$ Present address: Department of Molecular Biology, Albert Einstein College of Medicine, 1300 Morris Park Avenue, Bronx, New York I046r, U.S.A. 
Interstitial cells, with no visible evidence of specialization, occur in a spectrum of sizes either singly or in clusters. The significance of the various classes, however, was not recognized until Lehn (195I) made the important observation that interstitial cell clusters, defined as a set of adjacent cells dividing synchronously, generally contain $2,4,8$ or 16 cells. He also observed that nematocytes differentiate in clusters of 4,8 or 16 cells and suggested that they arose from the corresponding cluster of interstitial cells. From his studies he inferred that single interstitial cells were the true multipotent interstitial stem cell which initiated nematocyte differentiation by first dividing several times to produce a cluster and then elaborating a nematocyst capsule in each cell of the cluster. The electron-microscopic studies of Slautterback \& Fawcett (1959) showing that cells within a nest are joined together by cytoplasmic bridges was fully consistent with this scheme and provided a cellular explanation for the remarkable synchrony in division and cell differentiation.

Development of a maceration technique (David, 1973) for complete dissociation of hydra tissue into cells has greatly enhanced the analysis of interstitial cells. Maceration does not disrupt the cytoplasmic bridges between interstitial cells so that a preparation of dissociated cells contains single interstitial cells and interstitial cell clusters (David, 1973; Bode et al. 1973; David \& Challoner, 1974). In the present study we have determined the proliferation kinetics of all classes of interstitial cells in hydra in vivo. We have measured the lengths of $G_{1}, S, G_{2}$ and $M$ independently for each class of interstitial cell and summed these values to obtain the total cell cycle time for interstitial cells of each cluster size. The uniquely long and variable $G_{2}$ of large interstitial cells occurring singly and in nests of 2 suggest that their proliferation can be controlled in hydra. This strengthens the view that these cells represent the proliferative stem cell population. Calculations presented in the accompanying paper (David \& Gierer, 1974) further support this interpretation.

\section{MATERIALS AND METHODS}

Hydra attenuata were used for all experiments. The techniques of hydra culture, isotope labelling and autoradiography, tissue maceration, preparation of histological sections, and microfluorimetric analysis of nuclear DNA contents were described in the first paper of this series (David \& Campbell, I972). In autoradiographs labelled cells had ro-30 grains per nucleus while the background count was less than 3 grains per nucleus. Large steady state animals bearing 2 buds were taken from rapidly growing cultures (doubling time 3.5 days) for all experiments.

Interstitial cells occur singly or in clusters in hydra tissue. Dissociation of tissue by the maceration procedure used here does not disrupt interstitial cell clusters (David, I 973; David \& Challoner, 1974). Thus, interstitial cells have been characterized in the present experiments on the basis of cell size and morphology as well as cell number per cluster. The terminology used is that of David (1973). 'Large' interstitial cells occur almost always in clusters (nests) containing I, 2 or 4 cells; 'small' interstitial cells usually are found in nests of 8 or 16 cells. When intermediate numbers of cells were found in a cluster it was assumed to represent a cluster of the next higher geometrical number of cells. Histological sections were used for the labelled mitosis experiment because clusters of mitotic interstitial cells tend to break apart in the maceration procedure. For this experiment interstitial cells were classified solely on the basis of cell number per cluster. One cluster was defined as consisting of all contiguous cells of a similar mitotic stage taking into account cells on adjacent serial sections in each case. 


\section{RESULTS}

\section{Proliferative fraction of interstitial cells}

The overall proliferation kinetics were estimated by labelling hydra continuously with $\left[{ }^{3} \mathrm{H}\right]$ thymidine and assaying at intervals the fraction of interstitial cells labelled (Fig. I). Cells in a single nest are always either all labelled or all unlabelled following isotope injection. Some representatives of all classes of interstitial cells are labelled immediately, indicating that both large and small interstitial cells proliferate. About

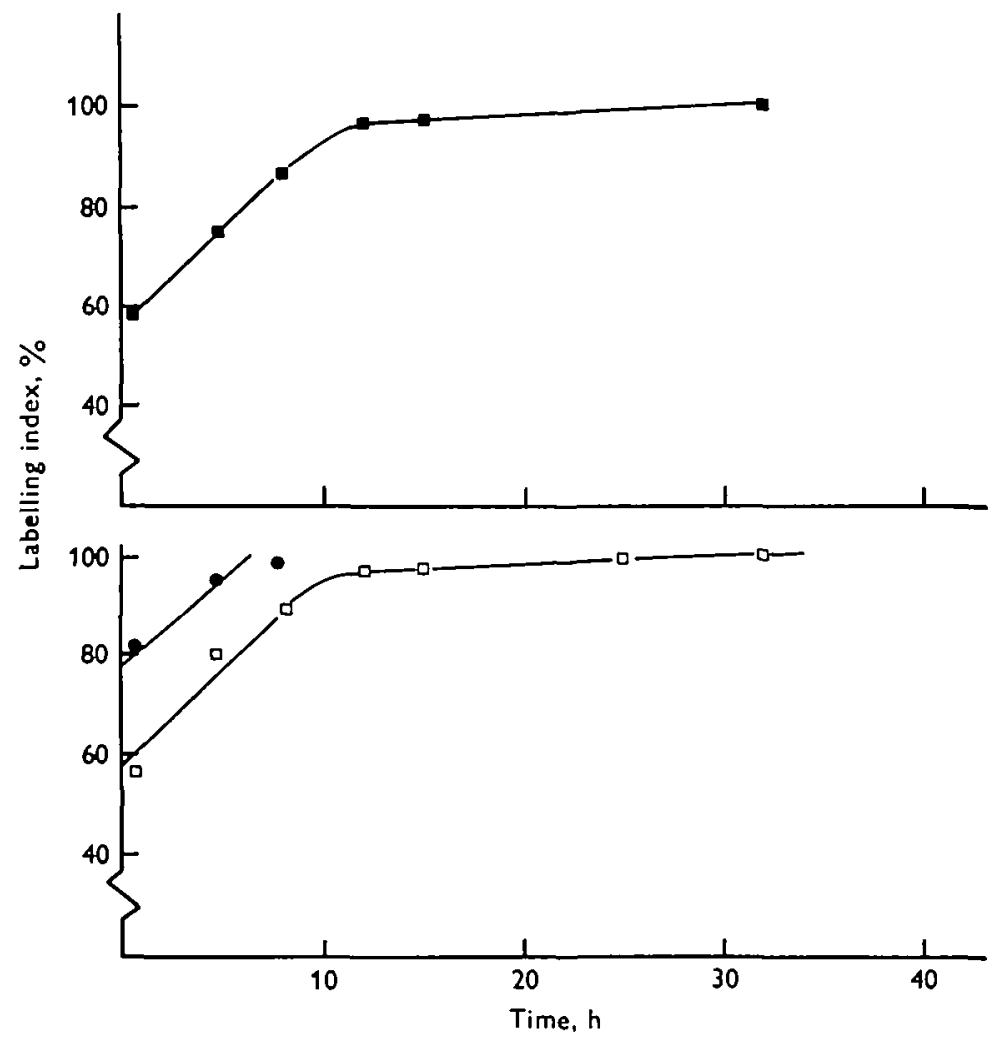

Fig. I. Labelling index of interstitial cells in hydra continuously labelled with $\left[{ }^{3} \mathrm{H}\right]-$ thymidine. Hydra were injected with $\left[{ }^{3} \mathrm{H}\right]$ thymidine $(10 \mu \mathrm{Ci} / \mathrm{ml})$ every $8 \mathrm{~h}$ starting at $t=0$. For each sample, 3 hydra were reinjected $30 \mathrm{~min}$ prior to the times indicated and then macerated. The labelling index of single interstitial cells and clusters of 2 and 4 cells was determined in autoradiographs of the macerations. $\square$, I cell/nest; $\square, 2$ cells/nest; 0,4 cells/nest.

$50-60 \%$ of the single and paired interstitial cells are labelled initially; this rises to about $95 \%$ within $\mathrm{I} 2 \mathrm{~h}$. About $80 \%$ of the nests of 4 are labelled initially and these nests are completely labelled within $4 \mathrm{~h}$. Continuous labelling kinetics of interstitial cells occurring in nests of 8 and 16 cells are more complex because these populations contain many postmitotic cells differentiating into nematoblasts (David \& Gierer, 1974). However, pulse-chase labelling experiments (C. N. David, unpublished observations) show that a large proportion of 8 -celled nests are proliferating $(69 \%$ are labelled 
by a $\left[{ }^{3} \mathrm{H}\right]$ thymidine pulse) whereas very few nests of $\mathrm{I} 6$ proliferate further $(5 \%$ are labelled by $\left[{ }^{3} \mathrm{H}\right]$ thymidine pulse). Furthermore, the level of labelling in nests of 8 and I6 increases dramatically upon further incubation in the absence of $\left[{ }^{3} \mathrm{H}\right]$ thymidine (pulse-chase experiment) indicating that the non-proliferating (unlabelled) fraction of 8 and 16 cell nests is turning over rapidly.

The labelling data indicate that all nest classes of interstitial cells contain proliferating cells. Large interstitial cells proliferate more slowly than the small interstitial cells. Since the length of time to reach $100 \%$ labelling in a continuous labelling experiment is equal to the length of the cell cycle minus the $S$-phase, the total length of the cell cycle (assuming an $S$ length of $\mathrm{II}-\mathrm{I} 2 \mathrm{~h}$; see below) is about $24 \mathrm{~h}$ for the large interstitial cells and $\mathrm{I} 6 \mathrm{~h}$ for the small interstitial cells. Thus, the large and small interstitial cell populations proliferate at rates about 3 and 4 times, respectively, the overall hydra growth rate (doubling time 3.5 days).

\section{Nuclear DNA contents of interstitial cells}

Nuclear DNA contents were determined microfluorimetrically in interstitial cells isolated from hydra which had been labelled with $\left[{ }^{3} \mathrm{H}\right]$ thymidine for $30 \mathrm{~min}$ and fixed immediately. We then assessed which of these cells were labelled using autoradiography on the same cell preparations. The results of one experiment are shown in Fig. 2. DNA contents of all interstitial cell types varied from about 3 to $7 \mathrm{pg} /$ nucleus. Most of the cells with intermediate DNA contents were found to be labelled with $\left[{ }^{3} \mathrm{H}\right]$ thymidine; these cells were therefore in the $S$-phase of the cell cycle. Unlabelled cells with DNA contents about $2 n$ were judged to be in $G_{1}$, and unlabelled cells with $4^{n}$ DNA contents were judged to be in $G_{2}$.

About half of the large, single interstitial cells were in $S$-phase, indicating that this phase occupies about one-half of the cell cycle. Most of the remaining large interstitial cells, were in $G_{2}$, indicating that this period is as long as the $S$-phase. The $G_{1}$ phase is apparently of very short duration or absent, for only I cell was found in this stage.

The profile of DNA contents of cells in nests of 2 is very similar to that of single interstitial cells. Cells are nearly equally distributed between $S$ - and $G_{2}$ phases, with very few cells having $G_{1}(2 n)$ DNA content. From the data in Fig. 2 concerning cells in clusters of 4 , one may conclude that the $G_{2}$ phase is short compared to the $S$-phase. Again, the $G_{1}$ phase is apparently absent or of very short duration. Because the clusters of 8 and 16 interstitial cells contain significant numbers of differentiating cells the profile of nuclear DNA contents cannot be used to determine the lengths of $G_{1}$ and $G_{2}$.

\section{$S$-phase duration}

The length of the $S$-phase was estimated by the $\left[{ }^{3} \mathrm{H}\right]$ thymidine $/\left[{ }^{14} \mathrm{C}\right]$ thymidine double-labelling technique of Wimber \& Quastler ( $\left(9^{6} 6_{3}\right)$. Hydra were labelled with a pulse of $\left[{ }^{3} \mathrm{H}\right]$ thymidine. After varying intervals several animals were relabelled with $\left[{ }^{14} \mathrm{C}\right]$ thymidine and sampled by maceration $30 \mathrm{~min}$ later. Cells which leave the $S$-phase between the 2 isotope pulses will be labelled with only $\left[{ }^{3} \mathrm{H}\right]$ thymidine. The ratio of 

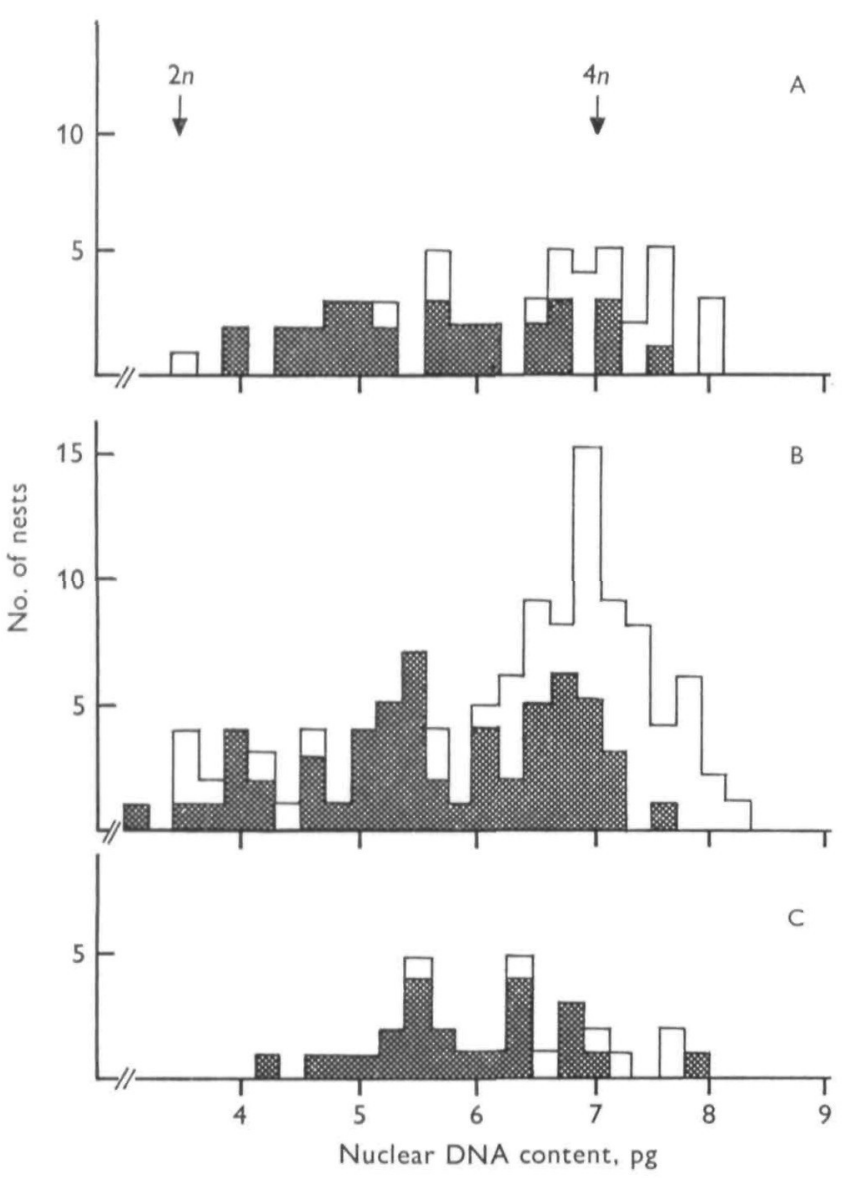

Fig. 2. Nuclear DNA content and [ $\left.{ }^{3} \mathrm{H}\right]$ thymidine incorporation in nests of $\mathrm{I}, 2$ and 4 interstitial cells. Five hydra were pulse-labelled with $[\mathrm{P} \mathrm{H}]$ thymidine $(\mathrm{I} \circ \mu \mathrm{Ci} / \mathrm{ml})$ and macerated $30 \mathrm{~min}$ later. The maceration preparation was stained with the fluorescent Feulgen reagent bisaminophenyl-oxdiazole and the nuclear DNA content of individual cells determined by microfluorimetry. In a second step the same cells were assayed for [ $\left.{ }^{3} \mathrm{H}\right]$ thymidine incorporation by autoradiography. DNA values for different cells in the same nest were always very similar as was the level of [ $\left.{ }^{\mathrm{H}} \mathrm{H}\right]$ thymidine incorporation. A, B, and C, 1,2 , and 4 cells/nest, respectively; $2 n$ and $4 n$ DNA values were determined on mitotic cells in metaphase and telophase; filled bars represent nuclei labelled with $\left[{ }^{3} \mathrm{H}\right]$ thymidine.

cells labelled solely with ${ }^{3} \mathrm{H}$ to all cells labelled with ${ }^{14} \mathrm{C}$ increases as the interpulse time increases. For any given interpulse time $(\Delta t)$ the relationship holds:

$$
{ }^{{ }^{3} H}=\frac{\Delta t_{1}}{S},
$$

where $S$ is the length of the $S$ phase, ${ }^{3} H$ is the fraction of cells labelled solely with ${ }^{3} \mathrm{H}$, and ${ }^{14} \mathrm{C}$ is the fraction of cells labelled with ${ }^{14} \mathrm{C}$ alone or with ${ }^{14} \mathrm{C}$ and ${ }^{3} \mathrm{H}$.

Data for 2 experiments are presented in Fig. 3 . It was necessary to restrict the interpulse interval to $2 \mathrm{~h}$ to avoid labelled cells passing mitosis. The $S$-phase duration 
obtained from the slope in Fig. 3 lies between 9 and $\mathrm{I} 3 \mathrm{~h}$ for interstitial cells in nests of I, 2 and 4 . An average value of i I h has been taken for calculations. The $S$-phase for nests of 8 was not determined by this method but was estimated from the labelled mitoses experiment (see below).

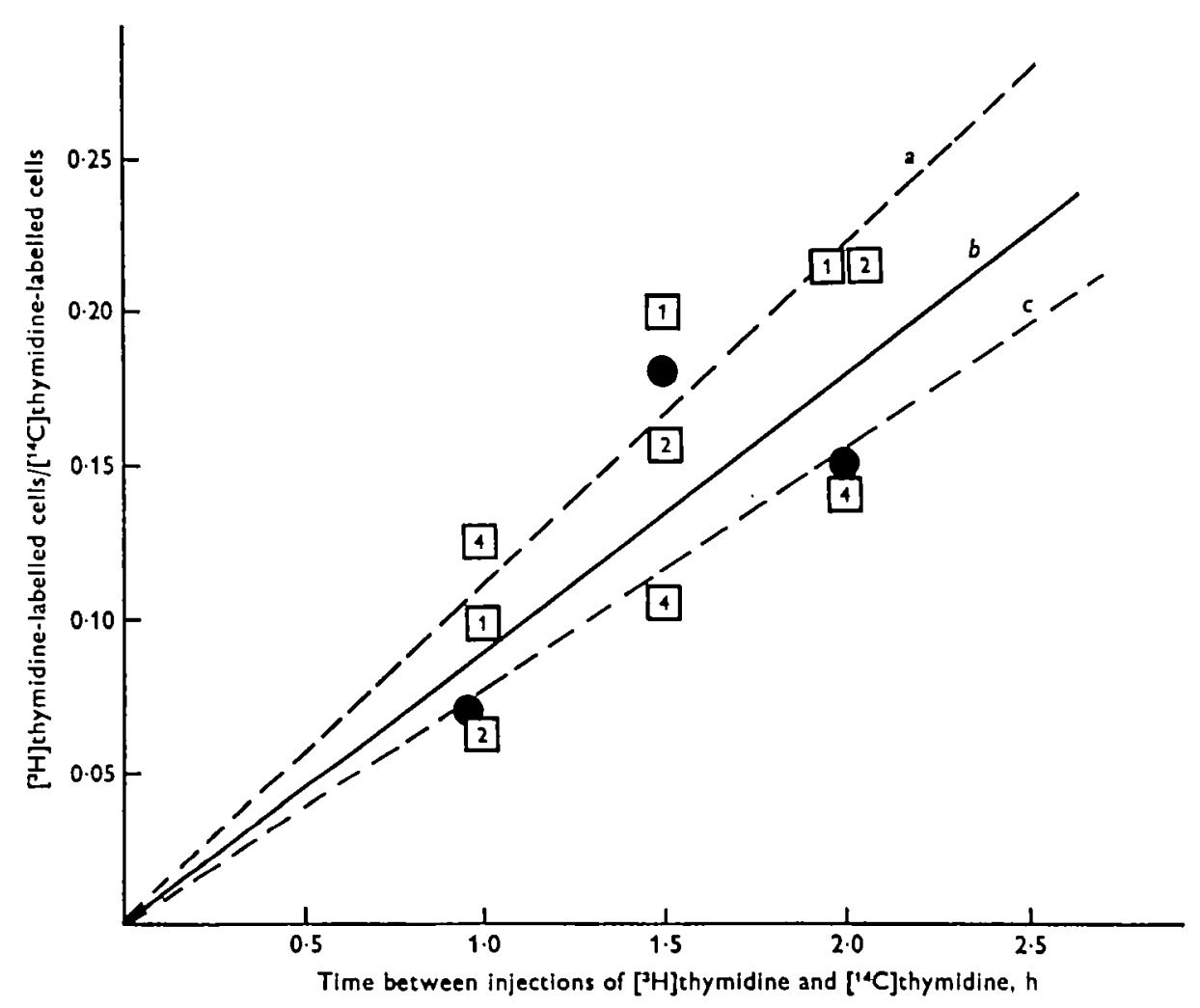

Fig. 3. Determination of the length of $S$-phase by $\left[{ }^{3} \mathrm{H}\right]$ - and $\left[{ }^{14} \mathrm{C}\right]$ thymidine doublelabelling. Hydra were injected with $5 \circ \mu \mathrm{Ci} / \mathrm{ml}\left[{ }^{3} \mathrm{H}\right]$ thymidine. After various intervals, 3 animals were reinjected with $20 \mu \mathrm{Ci} / \mathrm{ml}\left[{ }^{14} \mathrm{C}\right]$ thymidine and sampled by maceration $30 \mathrm{~min}$ later. Cell macerations were subjected to autoradiography using 2 film layers to distinguish cells labelled with ${ }^{3} \mathrm{H}$ and ${ }^{14} \mathrm{C}$. Labelled interstitial cell nests were scored in 2 classes: cells labelled only with [ $\left.{ }^{3} \mathrm{H}\right]$ thymidine and all cells labelled with $\left[{ }^{14} \mathrm{C}\right]$ thymidine. In one experiment nests containing $\mathrm{I}, 2$ and 4 cells were scored separately $(\square)$. In a second experiment all large interstitial cells wet e scored together (O). Ordinate: ratio of cells labelled only with $\left[{ }^{3} \mathrm{H}\right]$ thymidine to all cells labelled with $\left[{ }^{14} \mathrm{C}\right]$ thymidine. Abscissa: time interval between labelling with $\left[{ }^{3} \mathrm{H}\right]-$ and $\left[{ }^{14} \mathrm{C}\right]$ thymidine. The 3 lines $a, b, c$ show expected curves for $S$-phase durations of 9 , I I, and $13 \mathrm{~h}$, respectively.

\section{$G_{2}$ phase duration}

The length of $G_{2}$ was determined by the method of labelled mitoses (Quastler \& Sherman, 1959). Hydra were pulse-labelled with $\left[{ }^{3} \mathrm{H}\right]$ thymidine. After various intervals 2 hydra were sampled by fixing, embedding and sectioning for histology. Nests of interstitial cells in mitosis were located and mapped in sections. Following autoradio- 
graphy, these nests were scored for labelling with $\left[{ }^{3} \mathrm{H}\right]$ thymidine. The results are shown in Fig. 4.

The small interstitial cells in nests of 8 and $\mathrm{I} 6$ have the clearest pattern. Mitotic cells are $100 \%$ labelled within $4 \mathrm{~h}$ of labelling, indicating that $G_{2}$ is uniformly about

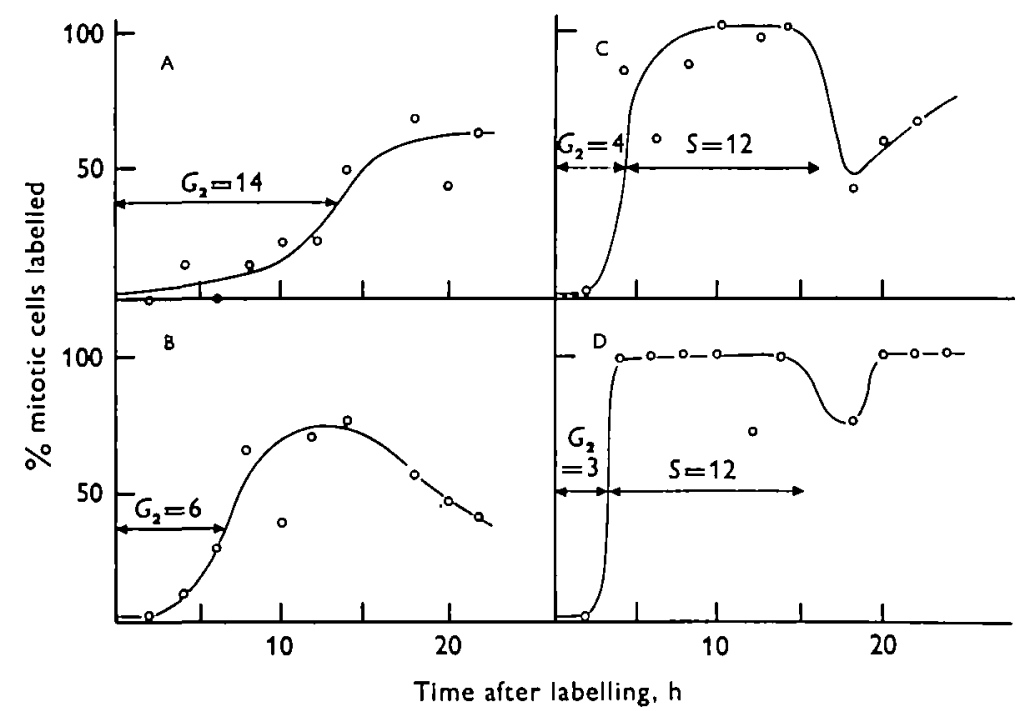

Fig. 4. Determination of $G_{2}$ by the method of labelled mitoses. Hydra were pulselabelled with $\left[{ }^{3} \mathrm{H}\right]$ thymidine $(10 \mu \mathrm{Ci} / \mathrm{ml})$. At 2 -h intervals thereafter, 2 hydra were sampled by fixing, embedding and sectioning for histology. Following autoradiography, nests of interstitial cells in mitosis were identified in sections and scored for cell number per nest and labelling with $\left[{ }^{3} \mathrm{H}\right]$ thymidine. The data represent analyses of 340 single interstitial cells (A), 240 2-cell nests (B), 2194 -cell nests (C), and I 42 8- and I6-cell nests (D) distributed about equally among the different time points. In drawing the curves less weight was given to data points which were based on particularly small samples. The estimated periods of the various portions of the cell cycle are shown by arrows.

$3 \mathrm{~h}$. After about $\mathrm{I} 6 \mathrm{~h}$ there is a marked drop in the frequency of labelled mitotic cells, followed by another rise to $100 \%$ at $20 \mathrm{~h}$. From the width of the first labelled mitotic peak one can estimate that the $S$-phase is about $12 \mathrm{~h}$. The short duration of the trough $\left(G_{1}+G_{2}+M\right)$ following the first peak is not much longer than the initial unlabelled period, indicating that for nests of 8 and 16 the $G_{1}$ phase is at most $\mathrm{I} h$ in duration.

Cells in nests of 4 showed a similar mitotic labelling pattern with a $G_{2}$ of about $4 \mathrm{~h}$. They did not quite achieve complete labelling, however, indicating that a few of these cells may have a somewhat longer $G_{2}$ period. However, during the second cycle these cells, now in nests of 8 , reach $100 \%$ mitotic labelling. Hence the few cells with a prolonged $G_{2}$ phase appear to drop out of the proliferating populations.

The labelled mitosis curves for single and paired interstitial cells are characterized by never attaining $100 \%$ labelling. Such a result indicates variability in the duration of $G_{2}$ for these populations significantly greater than the length of $S$-phase (I I-r $2 \mathrm{~h}$ ). In addition $G_{2}$ appears to be considerably longer than the $3^{-4} \mathrm{~h}$ measured for nests 
of 4,8 and 16 cells. Although the data are not extensive enough to permit a quantitative description of the $G_{2}$ variability in these populations, qualitatively the results are quite clear.

Interstitial cells in nests of 2 exhibit a predominant $G_{2}$ duration of about $6 \mathrm{~h}$. A second major population of cells having longer $G_{2}$ must also be present to account for ( $\mathrm{I}$ ) the low percentage ( $40 \%$ ) of labelled mitoses at $6 \mathrm{~h}$ and $(2)$ the $40-50 \%$ labelled

Table I. Cell cycle parameters of hydra interstitial cells

\begin{tabular}{|c|c|c|c|c|c|}
\hline Cells per nest & $G_{1}$ & $S$ & $G_{2}$ & $M$ & Total cell cycle \\
\hline $\mathbf{I}$ & $0-1$ & $I I-12$ & $\begin{array}{l}\text { Variable } \\
\mathrm{I} 4 \pm 8\end{array}$ & $\mathbf{I}$ & $27 \pm 8$ \\
\hline 2 & $0-1$ & $I I-I 2$ & $\begin{array}{l}\text { Variable } \\
\text { I } 4 \pm 8 \\
6 \pm 2\end{array}$ & $\mathbf{I}$ & $\begin{array}{l}27 \pm 8 \\
19 \pm 2\end{array}$ \\
\hline 4 & $0-I$ & I I-I 2 & 4 & I & $\mathrm{I}_{7}$ \\
\hline 8 & $0-1$ & $I I-I 2$ & 3 & $\mathbf{I}$ & 16 \\
\hline
\end{tabular}

The duration of each phase of the cell cycle for interstitial cells in nests of $1,2,4$ and 8 cells is shown. The data represent the best estimates based on all the results obtained. The total cell cycle duration was determined by summing all phases. All values are in hours.

Interstitial cells in nests of 2 appear to consist of 2 major subpopulations differing in the length of $G_{2}$; these have been listed separately. The small number of single interstitial cells with a short $G_{2}$ have not been included in the table. Rare nests of 16 proliferating interstitial cells have also not been included. They appear to have cell cycle parameters similar to nests of 8 cells.

mitoses at $20-22 \mathrm{~h}$. If we assume that nests of 2 consist of equal numbers of a subpopulation having $G_{2}=6 \pm 2$ and another having $G_{2}=14 \pm 8 \mathrm{~h}$, then the labelled mitosis curve (Fig. 4 ) is closely approximated. It would also be possible to fit the experimental data assuming one population with $G_{2}$ varying continuously from 4 to I 6 or from 2 to $18 \mathrm{~h}$. However, the fit to the experimental data is less good and thus we favour the idea of 2 populations.

Single interstitial cells show a delayed and gradual increase in frequency of labelled mitotic cells, indicating that these cells have a long $G_{2}$ phase and that there is considerable variability within the population. The rare cells having a short $G_{2}$ were also unusual in being small and frequently close to the mesoglea. Assuming that the average $G_{2}$ is $\mathrm{I}_{4} \mathrm{~h}$ and that the population is evenly distributed among cells having $G_{2}$ from 6 to $22 \mathrm{~h}\left(G_{2}=14 \pm 8\right)$, the experimentally determined labelled mitosis curve can be approximated quite well.

\section{Mitosis}

The duration of mitosis $\left(t_{m}\right)$ was estimated from the relationship

$$
t_{m}=\frac{M I \times T}{\ln 2}
$$

where $M I$ is the mitotic index and $T$ the population doubling time (Cleaver, 1967). 
The average mitotic index of interstitial cells is about $3 \%$. The total cell cycle time varies from 16 to $27 \mathrm{~h}$ (Table $\mathrm{I}$ ). Taking $24 \mathrm{~h}$ as an average the duration of mitosis is about $\mathrm{I} \cdot \mathrm{I} h$.

\section{DISCUSSION}

\section{Total cell cycle of interstitial cells}

Table i summarizes the results on the duration of each phase of the cell cycle for each class of interstitial cells. There was good consistency in the results obtained from the different methods used in this study. For example, the DNA/nucleus measurements (Fig. 2) and the labelled mitosis experiment (Fig. 4) show that $G_{1}$ is less than I $\mathrm{h}$ in length for all interstitial cells. The duration of $S$-phase was estimated to be about i $\mathrm{h}$ by the double-labelling experiment (Fig. 3 ) and about $\mathrm{I} 2 \mathrm{~h}$ by the labelled mitosis experiment (Fig. 4). In contrast to the present data, Moore (197I) has reported that all interstitial cells contain a $2 n$ DNA complement. While he used sexual hydra of another species (H. cauliculata), it should be noted that we have also confirmed our findings that large interstitial cells have predominantly $4^{n}$ DNA contents in Pelmatohydra oligactis and Chlorohydra viridissima. Moore did not clearly define what he termed an interstitial cell, so it is not possible for us to explore the discrepancy between our results.

The total cell cycle time for each class of interstitial cell has been obtained by summing the times for all phases, as shown in Table $\mathrm{r}$. The results are consistent with the continuous- and pulse-labelling data (Fig. I and text) for each nest size. For example, $75-80 \%$ of nests of 4 cells (Fig. I) are labelled by a pulse of $\left[{ }^{3} \mathrm{H}\right]$ thymidine which is consistent with a 12 -h $S$-phase in a 17 -h cell cycle (Table I). Furthermore, at least $95 \%$ of these nests are labelled after $4 \mathrm{~h}$ continuous labelling with $\left[{ }^{3} \mathrm{H}\right]$ thymidine. Even for the complicated case of a mixed population of nests of 2, the pulse- and continuous-labelling data (Fig. I) agree to within $5 \%$ with curves calculated from the parameters listed in Table $\mathrm{I}$.

\section{Interstitial cell proliferation and differentiation}

The cell cycle parameters of large and small interstitial cells are very different. For small interstitial cells the total cell cycle time is about I $6 \mathrm{~h}$. Nearly all of this is occupied by the $S$-phase, which is I I-I2 h. Thus, small interstitial cells appear to be proliferating at the maximum possible rate. By comparison, the cell cycle lengths of most single interstitial cells and at least half of the nests of 2 are heterogeneous and on the average about $\mathrm{I} .5$ times longer than cells in nests of 8 and $\mathrm{I} 6$. This heterogeneity is due entirely to the variable length of $G_{2}$. In this regard these interstitial cells resemble epithelial cells in hydra (David \& Campbell, 1972). The variable $G_{2}$ suggests it as a possible control point in the proliferation and/or differentiation of these cells.

Interstitial cells in nests of 4,8 and 16 are the immediate precursors to nests of differentiating nematoblasts (Lehn, 1951; Slautterback \& Fawcett, I959; Rich \& Tardent, I969; David \& Challoner, I974). Large interstitial cells, both single cells and those in nests of $\mathbf{2}$, have been shown to include uncommitted stem cells (David \& 
Gierer, 1974). Thus, we view the progression of interstitial cells through nests of increasing cell number as proceeding toward a differentiated state. Our observations are consistent with the idea that cells which are determined to differentiate nematocytes have a short cell cycle and that the undifferentiated and uncommitted interstitial cells have a long cell cycle, including a $G_{2}$ phase of variable duration.

The authors thank Professor F. Ruch of the Eidgenössische Technische Hochschule, Zürich, for the use of his equipment for microfluorimetric DNA determinations. Miss Diane Challoner provided excellent technical assistance. This research was supported by the Max-PlanckGesellschaft and a Helen Hay Whitney Postdoctoral Fellowship to C. David, and NSF Research Grant GB-29284 and NIH Research Development Award I-KO4-GM42595 to R. Campbell.

\section{REFERENCES}

Bode, H., Berking, S., David, C. N., Gierer, A., Schaller, H. \& Trenkner, E. (ig73). Quantitative analysis of cell types during growth and morphogenesis in hydra. Willeelm Roux Arch. EntwMech. Org. 171, 269-285.

BURNETT, A. L. (I 968 ). The acquisition, maintenance and lability of the differentiated state in hydra. In The Stability of the Differentiated State (ed. H. Ursprung), pp. 109-1 27. Berlin: Springer-Verlag.

Cleaver, J. R. (1967). Thymidine Metabolism and Cell Kinetics. Amsterdam: North-Holland Publishing.

David, C. N. (1973). A quantitative method for maceration of Hydra tissue. Wilhelm Roux Arch. EntwMech. Org. 171, 259-268.

David, C. N. \& Campeell, R. ( 1972 ). Cell cycle kinetics and development of Hydra attenuata. I. Epithelial cells. F. Cell Sci. Ir, 557-568.

David, C. N. \& Challoner, D. (1974). Distribution of interstitial cells and differentiating nematocytes in nests in Hydra attenuata. Am. Zool. 14, 537-542.

David, C. N. \& Gierer, A. (I974). Cell cycle kinetics and development of Hydra attenuata. III. Nerve and nematocyte differentiation. F. Cell Sci. 16, 359-375.

LehN, H. (I95I). Teilungsfolgen und Determination von I-Zellen für die Cnidenbildung bei Hydra. Z. Naturf. 66, 388-391.

Lentz, T. L. (1966). The Cell Biology of Hydra. Amsterdam: North-Holland Publishing.

Moore, G. P. M. (I97I). Cytophotometric studies on nucleic acids and basic proteins during somatic and germinal differentiation of the interstitial cells of Hydra cauliculata (Hyman, 1938). Expl Cell Res. 69, 307-312.

Quastler, H. \& Sherman, F. G. (1959). Cell population kinetics in the intestinal epithelium of the mouse. Expl Cell Res. 17, 420-438.

Rich, F. \& TARDENT, P. (I 969). Untersuchung zur Nematocyten-Differenzierung bei $H y d r a$ attenuata. Rev. suisse Zool. 76, 779-789.

Slautterback, D. B. \& FAwCETt, D. W. (1959). The development of the cnidoblasts of Hydra. An electron microscope study of cell differentiation. F. biophys. biochem. Cytol. 5, 44I-452.

Wimber, D. E. \& QUastLeR, H. (1963). ${ }^{14} \mathrm{C}$ - and ${ }^{2} \mathrm{H}$-thymidine double labeling technique in the study of cell proliferation in Tradescantia root tips. Expl Cell Res. 30, 8-22.

(Received 4 March 1974) 